\title{
Developing Web-based English Instructional Material Oriented to Promote Independent Learning at Indonesian University Context
}

\author{
Aminah Suriaman \\ Faculty of Teacher Training and Education, Tadulako University, Palu Central Sulawesi, Indonesia \\ Asfah Rahman \\ State University of Makassar, Makassar South Sulawesi, Indonesia \\ Nurdin Noni \\ State University of Makassar, Makassar South Sulawesi, Indonesia
}

\begin{abstract}
The objective of this research is to develop web-based English instructional materials which enable to promote students' independent learning at university context. To comprehend this objective, the researcher employs R \& D (Research and Development) design by mixing quantitative and qualitative methods. This research is conducted at Faculty of Engineering Tadulako University. The subjects of the study are the lecturers who teach English for the general course and the students of faculty of Engineering. Subject matter experts were also involved to validate the product. The data were collected through semi-structured interview; study the related documents and the results of questionnaire distribution. The data in these phases were analyzed quantitatively and qualitatively. In reference to data analysis, five findings are documented as explored in this part of the article. In summary, the development of web-based English instructional materials oriented to promote independent learning is effective and responded positively both lecturers and students. With the various supported activities and along with the flexible learning atmosphere and methods of delivery, the web-based English instructional materials are effective to promote students' independent learning.
\end{abstract}

Index Terms —instructional material, material development, web-based instruction, independent learning

\section{INTRODUCTION}

The demand for mastering the English language has been increasing steadily because of advancement in science and information technology. The language status as the international language of diplomacy and trade has also contributed to the need for English learning. Many of today's most valuable sources of information are available primarily in English. Many claims that the English language is one of the main foundations of globalization (Johnson, 2009).

As part of today's globalized society, Indonesia has placed particular focus on the teaching and learning of English. The government has established English as one of the core subjects which is taught in formal, informal and non-formal education. Although English has been taught for years at school, it has not produced the expected results. The students' poor proficiency in English as indicated by PISA (Program for International Student Assessment) may be caused by some factors like students' characteristic, norms, and beliefs, students aspect as well as teachers factor who delivered the instruction (Jalal, Samani, Chang, Stevenson, Ragatz, \& Negara, 2009). Such conditions are among other caused by the learning strategies of the students who still tend to copy what teacher note down on the blackboard and adopt memorization (Sri Lengkanawati, 2005). The teacher-centered instructional approach in which the teacher does most of the talking and activities leaves little time for students to practice their English. This is the consequence of a teaching and learning process that is still teacher-centered. As a result, students become dependent on the teacher to guide them in learning the language.

The phenomenon has contributed to the dependency of most Indonesian students on the teacher and led them to teacher center due to the domination of the classroom by teachers. As a consequent, students have a limited time to learn and practice English both in groups and individually. This has made the process of English language teaching in Indonesia harder for students (Suriaman, 2015).

Another factor as the determinant of the effectiveness of instruction and learning is the planning of teaching done by teachers. A learning plan is not just to complete the administrative needs and the curriculum, but it must be designed with the involved components of the instructional design. It includes instructional objectives that begin with an instructional analysis, students' need analysis and the context, formulate performance targets, the development of assessment instruments, the development learning strategies, the design and selection of materials, and develop and conduct the formative evaluation (Yaumi, 2013). 
The development of teaching materials was undertaken within the procurement of printed materials such as handouts, summaries of materials, and the materials in the form of a Power-Point presentation. Other publications such as books and the module are still very limited as well as teaching materials produced in the form of audio, visual and multi-media that are integrated with Information and Communication Technology (ICT). Moreover, the module or commercial materials used for teaching and learning process are usually not in line with the students need because there is no students need analysis conducted before developing the materials. Therefore learning materials delivered tend to not attract the interest of students (Yaumi, 2013).

Despite the universal recognition of the importance of English at the tertiary level, the issues stated above have to some extent de-motivated students to learn the language. To make the students interested in learning the language, a more relaxed and unbound learning environment is essential. One way of creating such an environment is by encouraging the students to apply the concept of independent learning in which students are required to be more independent in selecting their learning materials and methods to fit their preferences (Sheerin, 1997). Further, she stated that independent learning has frequently been used to welcome this significant change, which has specific aims that teacher, pays more attention to the learner's needs, wants, interests, and abilities.

Independent learning is a learning approach, which purposes to promote the development of learners' autonomy and independence and targets for the students to acquire life-long learning skills (CIEL Project, 2000). The instructional situation is created that the responsibility is heavily placed on the student. In addition, this learning approach is an essential part of both learning and teaching process in which students can expand their knowledge and develop selfmanagerial skills.

Most importantly, independent learning enables students to learn by following a guide that suits their needs and preference (Knight, 1996). It can be concluded that this type of learning simply means that in an independent learning atmosphere, an individual learner, or with others, the learning does without the teacher's direct control. Responsibility for learning is the key to this concept.

As stated by Aminah (2016), autonomy and students' participation is an integral part of the process of independent learning. Independent learning is supported when students have the will and value learning process. The teacher, in this matter, has the responsibility to develop learning materials and techniques that are relevant to students' needs. The teachers also have a significant role in carrying out instructions in the learning process, which students' look up to. Therefore, in order to develop methods to encourage independent learning, it is necessary to choose appropriate teaching technique and media that can cover all the problems faced by the students. In my point of view, by integrating technology such as the internet as a medium in the process of teaching and learning, it is potential to add the value to the learning process and to increase students' attention and motivation.

Technological process and development over the years have significantly shaped the way languages are taught and learned (Tabatabaei\&Gui 2011). Technological tools such as computer technology help learners for language acquisition at the same time motivate them to learn as research has shown that students have high motivation in learning when the learning process involves technological tools (Jaeglin, 1998). The instructional process by integrating technology is likely to make teaching more successful and more attractive. Technology is used in almost every aspect of instruction and learning (Mahmoudi, Samad, \& Razak, 2012)and it has been known to promote and facilitate learning.

Being aware of the problems faced by both teachers and students and the urgencies of creating active learning activities in university particularly at Tadulako University, it is necessary to design and develop Web-based instructional materials, which are able to promote independent learning. Therefore, the researcher applied varieties different medium/tool in developing materials namely Web-based English instructional materials for improving students' independent learning. To maximize the educational value of web-based English instructional materials, the researchers will explore the websites' arrangement and practicalities. The basic tools required in the design of instructional websites include the tools of navigation, response time, the sites' reliability, and its substances (Nielsen, 2000). Moodle 2.0 Website is the web application used in order to have the basic tools required for the instructional web.

\section{REVIEW OF LITERATURE}

The rapid development of technology along with the significant increase in the use of it has made the internet as of today's basic daily needs to many people in many parts of the world. The World Wide Web as the feature of the Internet is now being included as instruction and instructional support in many fields including education. Olson and Wisher published their research in 2002 which focused on the effectiveness of Web-based instruction. The research reviews 47 reports of evaluations of Web-based courses in higher education in between 1996 and 2002 particularly in the United States and European countries. It found out that the Web-based instruction offers many advantages including flexibility, enrollment, and management.

\section{A. Instructional Materials}

Instructional materials play a crucial role in an EFL setting. Therefore, the teachers are demanded to have innovative teaching methods and IT skills when it comes to instructional materials. (Ismail, 2015).As the instructional material in 
the field of language teaching may be referred as many things, in this matter it may be referred as the tools used by the teachers to help the students in language acquisition.

Numbers of scholars prove that instructional materials highly facilitate learning and greatly draw learners' attention to the target language. In his book, Richards argued that the basis of language input that learners receive and practice in the classroom are the instructional materials. Therefore, it is crucial that the materials can lure students' motivation and interest to learn (as cited in Cakir, 2015). This argument is also supported by Noam Chomsky who stated that most of the teaching process is to make the students interested in the materials given. In order to achieve that, teachers shall find additional techniques in making the materials for foreign language learners more fascinating (as cited in Cakir, 2015. Furthermore, Tomlinson said that there are 5 classifications of instructional materials for language teaching including informative (informing about the target language); instructional (the materials is able to assist the learners to practice the language); experiential (providing experience on the language for the learners); eliciting (it sparks the learners' motivation and interest to use the language); and finally, exploratory (it triggers the learners to explore the use of the language) (as cited in Cakir, 2015).

\section{B. Materials Development}

Materials development refers to anything which is done by writers, teachers or lecturers to provide sources of language input (Tomlinson, 2003). It also relates to the supplying of information about the language in ways designed to promote language learning. In order to conduct this, materials developers, including teachers or lecturers, may bring pictures or advertisements in the classroom, compose a textbook, design a student workbook, audio or video materials, or an article.

\section{Web-based Instruction}

Web-based instruction has received growing popularity and consideration in the recent years. According to Khan (1997), Web-based Instruction (WBI) can be referred as a hypermedia that uses the features and resources of World Wide Web in creating a learning environment where the learning process is encouraged. Web-based instruction is the emergence and development of a new form of technology-supported education. Web-based instruction can also be referred as a media that utilizes hypermedia and multimedia technology and aim to provide learners with a learning environment where the user has control of and it has the ability to adapt to the users' different learning needs (Kern $\&$ Warschauer, 2000). McCormack and Jones (1998) also contributed in defining web-based instruction in which he argued that it can be utilized as an archive where students can find and recall the materials that can be useful for their learning process. Moreover, the internet not only becomes a media that provide texts and information but can go beyond that where we can take advantage of the features of the internet to make students learn better with materials that they find more relatable. Concisely, Web-based Instruction can be referred as utilizing the World Wide Web as a platform to give course materials, manage additional teachings and quizzes and as an alternative platform from the classroom for students and teachers to communicate (as cited in Hui \& Cheung, 1999).

Web-based instruction provides a variety of approaches to the use of online resources to help promote student learning and, as a result, many institutions across all disciplines implement Web-based instruction in their teaching. Web-based instruction is the emergence and development of a new form of technology-supported education (Khan, 1997)

Web-based instruction is seen as a platform that highly supports the excellent learning environment. Due to its features and advantages that support the teaching and learning process, educational institutions using the platform keep increasing. There are many advantages offered by the WBI mentioned by Erricolo and Raymond (2008) including; a) students who are professionally attached with their work or have other commitments or limited financial resources and thus unable to frequently attend the classrooms, will still be able to study and participate in the learning process by taking advantage of the WBI where they can access the materials not only from classrooms; b) The unlimited access by time and place offered by WBI can eliminate issues such as schedule conflicts; c) An electronic format of materials, which is one of the features of WBI eases the instructors to modify and keep the materials updated; d) Materials are organized under one repository so that the sources for materials are centralized and accessible; and finally, e) WBI allows, encourages and supports users particularly instructors to use visual images and this feature helps in enhancing the clarity of the course materials for the students.

\section{Independent Learning}

One of the remarkable changes in recent years in English Foreign Language (EFL) classroom has been an increasing attention to the role of the learner and the process of learning and acquisition of the language. A various term such as self-instruction, individualized instruction, personalized learning, humanization of the classroom, self-directed learning, and self-centered teaching approach, or independent learning have been used interchangeably. Although sound different, all the names share one particular point; teacher more attention towards the learner's needs, wants, interest, and abilities.

Independent learning is a concept that describes a progress to the learner-centered education system where it is acknowledged that each student has unique learning needs. (CIEL Project, 2000).Liu (2013) confirms that in the system of independent learning, the teachers give instructions and guidance for the students and facilitate the learners' initiatives and participation. Outside the classroom, the students are mostly responsible for their own learning wherein 
language learning particularly, autonomous learning is extremely essential. The learning process for language learning consists of two integral parts including the classroom and the outside-classroom activities. In classroom, the teachers are expected to give instructions while the learners are expected to carry out these instructions outside (Liu, 2013).

The system of independent learning has expanded learning environment beyond classroom where students can learn from variety of learning environments. Liu (2013) also added that in the system of independent learning, it is necessary for the teachers to habituate the students on autonomous learning. At first, the teachers are expected to facilitate in terms of determining the learning arrangements such as the learning time and content while also encouraging the students' independent learning approaches. Over a period, the students should be able to determine the contents that are in accordance with their need and also independently choose their own timing in completing the learning tasks. In order to create an ideal learning environment, however, the teacher should still ensure the process of the students by strengthening the management and supervision and also give adequate level of pressure.

\section{METHODOLOGY}

This study is categorized as research and development design by mixing quantitative and qualitative methods which focus on the development of web-based English instructional materials to promote independent learning for students of Informatics Tadulako University. This research is conducted at Faculty of Engineering Tadulako University. The subjects of the study are the lecturers who teach English for general course and the students of informatics faculty of Engineering Tadulako University. Subject matter experts were also involved to validate the product. The data were collected through semi-structured interview; study the related documents and the results of questionnaire distribution. The data in these phases were analyzed quantitatively and qualitatively.

\section{FINDINGS AND DisCUSSIONS}

In reference to the needs analysis, the following presents some findings. The present condition of the teaching of General English Course in Tadulako University is critical. The current teaching method shows that the frequency of students practicing English language skills in classroom is low particularly on listening and speaking skill. Students are aware of the importance of the language skills in which the data shows that the four language skills' importance to students reached the percentage of $84.7 \%$ meaning that the students consider them to be very important. However, the reality presents that the teaching method and materials have not yet increased students' capabilities in the four language skills. This is proven by many students still find the four language skills namely listening, speaking, writing and reading skills to be difficult.

As shown in the analysis of existing syllabus and content of the materials, they are not designed based on students' needs and expectation. Most of the meetings are dominated by lecturers' talk, explaining about structure, or enquiring students to write, lack of exploring students to be more active in classroom while students' needs and expectations show the need for interactive learning and teaching process. As shown in the students' need analysis, students are expecting the materials designed by involving technology that can enhance learning.

In measuring the needs of the students, the researcher tries to find out the present condition of students' capabilities in learning English and also their expectation. This includes their objectives in learning English, how they think English materials should be delivered in terms of language orientation, the endorsement of the four language skills within the course, the learning topics, and their learning preferences.

Students disclosed their main objectives and perceptions on the goal of learning English and the finding showed that the learning objectives are mainly for enhancing their ability in communication, as one of the important qualifications for seeking jobs and most importantly so that they can be able to prepare themselves for studying abroad. However, their expectations on learning English are not parallel with the present condition particularly on the methods of materials delivery, the boring materials and most importantly on its irrelevance of the materials with their needs. It is seen on how $86.2 \%$ students think that the present condition does not meet their expectation and needs.

The issue of disparity between the present materials offered to students and the students' needs is not the only problem. In a slow-developing rate province like Central Sulawesi particularly Palu city in terms of technology, has also impacted on the education process within the province and city. Students are highly dependent on the lecturers for their learning process. In fact, students fully rely on their teacher authority or in other words, teacher-centered classroom. This situation leads students to become discouraged in learning English and most importantly hinders their potential in developing good English skills.

As the world is rapidly developing to a digital era, Indonesia is also largely affected. In Indonesia alone, the number of internet users has reached 73 million people or 295 of its population (The Jakarta Post, 2015). Within our society, we may find the significant use and importance of the internet in supporting our daily life. Information is nowadays accessed through internet including knowledge. Online classes are becoming more frequent, class sources such as journals, thesis, articles and electronic books are signs that the internet may present as modern library for students. With the growing importance of the internet, the frequent uses of the World Wide Web to surf for information, and most importantly the needs for students to learn independently and access knowledge not dependent on the teachers, the researcher is highly enticed to develop Web-based instructional materials in Tadulako University. 
The exclusive feature of Web-based instructional materials is how it offers learners to unparalleled access to instructional resources that surpasses the reach of the traditional classroom (Olson \& Wisher, 2002). The flexibility of the learning atmosphere allows students to access the materials anytime and anywhere. This lets them to not solely depend on the teachers and classroom to study. Its accessibility creates continuous practice of students accessing materials on their own and eventually promotes independent learning in the future if it maintained in a sustainable routine. Therefore, the web can work as a solution to the issues found in classroom. This is proven by the use of the web-based instructional that has increased in universities around the world with an increased rate of $100 \%$ annually (Hartono, 2000).

As evidenced by the studies reviewed here, one can conclude that when teaching and learning are conducted with the help of web-based instruction, the students' learning ability and their eagerness to participate in the learning process can be enhanced. The Web-based also supports the learners to become independent learners who are responsible for their own learning.

Moreover, Web-based learning also encourages the students to be autonomous learners.

In reference to the impact of the web-based English instructional materials on promoting students' independent learning through gathering students and lecturers' opinions from distributed questionnaires and interview. The findings of students' opinion can be seen below:

\begin{tabular}{|l|l|l|l|l|}
\hline No & Statements & Score & Percentage & Classification \\
\hline 1 & $\begin{array}{l}\text { Learning English via Web-based Instructional model is a modern } \\
\text { way of learning. }\end{array}$ & 3.87 & $96.8 \%$ & Strongly Agree \\
\hline 2 & $\begin{array}{l}\text { Learning English via Web-based instructional model is convenient } \\
\text { to learn, the lessons can be reviewed anywhere and anytime. }\end{array}$ & 3.94 & $98.6 \%$ & Strongly Agree \\
\hline 3 & $\begin{array}{l}\text { Learning English via Web-based instruction is the way to enhance } \\
\text { your self-directed learning. }\end{array}$ & 3.80 & $94.9 \%$ & Strongly Agree \\
\hline 4 & Learning English via Web-based instructional model is enjoyable. & 3.93 & $98.1 \%$ & Strongly Agree \\
\hline 5 & $\begin{array}{l}\text { Learning English via Web-based instruction doesn't make you feel } \\
\text { isolated or alone. }\end{array}$ & 3.81 & $95.4 \%$ & Strongly Agree \\
\hline 6 & $\begin{array}{l}\text { Learning English via Web-based instructional model is useful in } \\
\text { learning English }\end{array}$ & 3.89 & $97.2 \%$ & Strongly Agree \\
\hline 7 & $\begin{array}{l}\text { Learning English via WBI helps you remember more new English } \\
\text { words. }\end{array}$ & 2.83 & $70.8 \%$ & Agree \\
\hline 8 & $\begin{array}{l}\text { Learning English via Web-based instructional model has clear } \\
\text { explanation of contents and exercises. }\end{array}$ & 2.98 & $74.5 \%$ & Agree \\
\hline 9 & $\begin{array}{l}\text { Learning English via Web-based instruction has the appropriate } \\
\text { contents with learning objectives. }\end{array}$ & 3.80 & $94.9 \%$ & Strongly Agree \\
\hline 10 & $\begin{array}{l}\text { Learning English via Web-based instructional materials is easy to } \\
\text { understand the lessons. }\end{array}$ & 3.33 & $83.3 \%$ & Strongly Agree \\
\hline 11 & $\begin{array}{l}\text { Overall, learning English via Web-based instructional materials is } \\
\text { satisfied. }\end{array}$ & 3.80 & $94.9 \%$ & Strongly Agree \\
\hline Average Score & $\mathbf{3 . 6 3}$ & $\mathbf{9 0 . 9 \%}$ & Strongly Agree \\
\hline
\end{tabular}

As seen from the table above, the data obtained reveals that the total average score of the questionnaire is 3.63 with the percentage $90.9 \%$. This value indicates that the students had very good opinions toward learning English via Webbased instruction.

Considering each item, the students agree that learning English by using Web-based instruction is modern, with the highest percentage $96.8 \%$. They agree that learning via Web-based instruction is useful. Students also agree that it is convenient for them to learn using the Web-based instruction because the system that allows them to review the materials anytime and anywhere (98.6\%). Learning via Web-based instruction is a way to enhance their self-directed learning $(94,9 \%)$ and this way of learning can help them remember more new vocabulary $(70.8 \%)$ which is classified as agree. The students agree that learning via Web-based instruction is enjoyable with the percentage score $98.1 \%$ and easy to understand the lessons with the percentage score $83.3 \%$. They agree that learning English via Web-based instructional materials has clear explanations of contents and exercises with the percentage score $74.5 \%$. The students express that learning English through Web-based instructional materials do not make them feel isolated or alone with the highest score $95.4 \%$.

In conclusion, according to the percentage score of the questionnaire, $90.9 \%$ classified as strongly agree. It shows that the students had very good attitudes toward learning English via Web-based instructional materials. Having good attitudes and highly motivated are indicators of independent learning attitudes.

With regard to the answered by the lecturers toward the appropriateness of the Web-based instructional materials that have been developed. The data are shown in the following figure: 

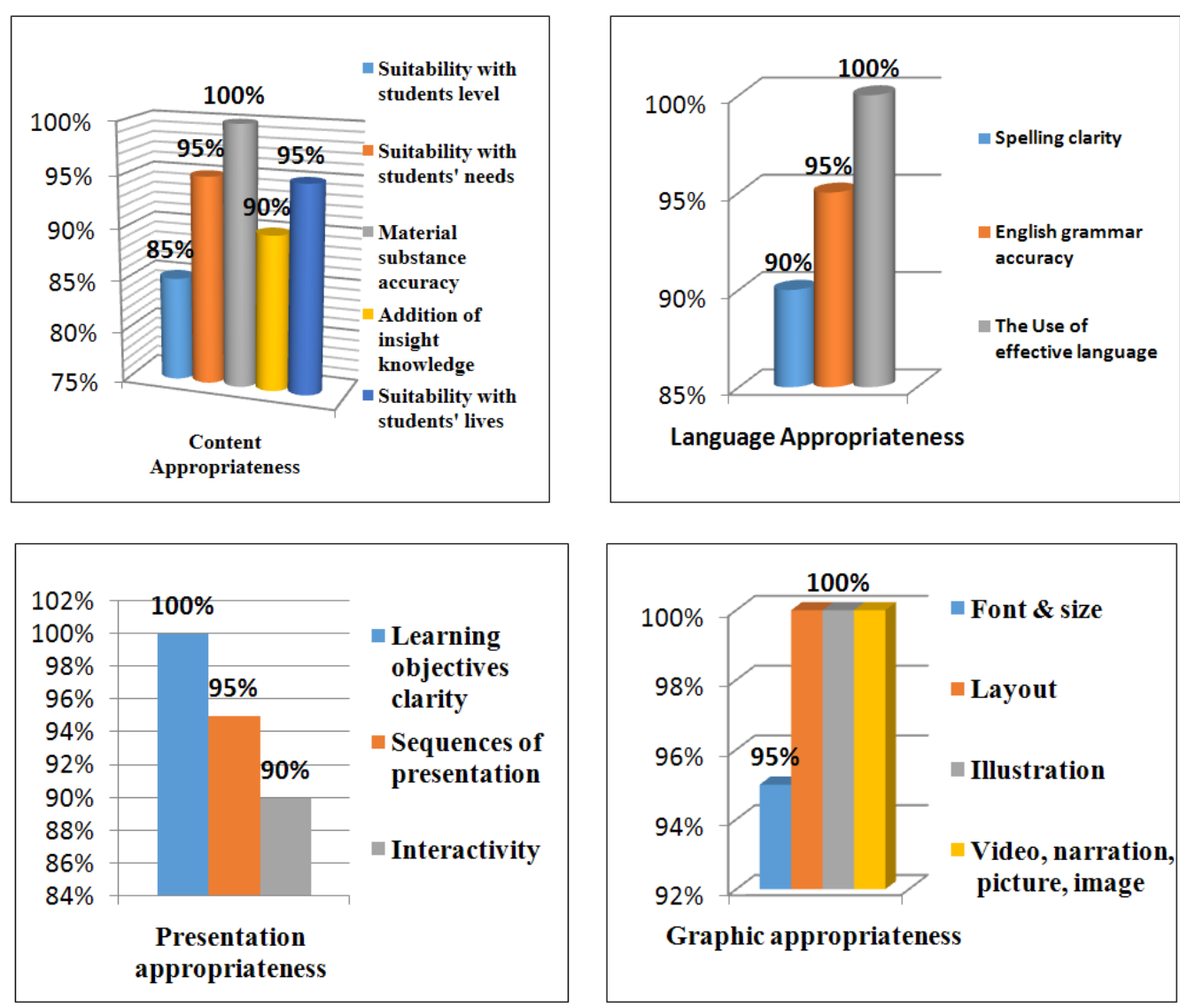

From the above data, it can be comprehended that the contents within the Web-based instructional materials meet the students' level of capabilities as well as meet their needs shown from the high percentages which are above $80 \%$. The materials substances are accurate and can improve students' insight of knowledge. Moreover, according to the lecturers asked, the Web-based materials are very contextual and in accordance with students' daily lives.

In terms of language appropriateness, from spelling, grammar and also the use of effective language meaning its punctuation, choices of words, from the chart above, we can see that it meets the criteria as it shows percentages all above $90 \%$.

In terms of the appropriateness of presentation; the learning objectives are very clear as well as a chronologicallybased presentation sequences. Moreover, within the presentation, interaction features are present to allow students and the speaker to have a virtual interaction.

From the appropriateness of graphic, the font and size, as well as layout, are user-friendly and clear, according to the lecturers. The illustrations provided are also very attractive. The availability of videos, pictures, and narrations are also attractive to learners and are appropriate for students. Finally, the average score of lecturers' responses is $95.3 \%$ which indicates that from the content, language, presentation, and graphics overall shows suitability both by English materials standard and to students.

In reference to the assessment of the produced design form the experts in Instructional Systems Technology and English Language Teaching field to validate the materials. The validation of the materials is needed to see whether the instructional materials were applicable or not. There are seven components that are observed; content, text, video, audio, image, animation, and interactivity. To validate the materials, a rubric is provided and filled out by the experts. The criteria of the collected data from the four-point rating scale rubric $(4=$ very appropriate, $3=$ appropriate $2=$ inappropriate, 1 = very inappropriate). The results of the validation are shown in table below: 


\begin{tabular}{|c|c|c|c|c|}
\hline $\begin{array}{l}\text { Indicator } \\
\text { Scores }\end{array}$ & Statement & Average & Percents & Classifications \\
\hline \multirow[t]{6}{*}{ Content } & Topics presented are very interesting and actively engaged in learning & 3.4 & $85.0 \%$ & Very appropriate \\
\hline & The design of the presentation displays all skills relevant to students' level & 3.8 & $95.0 \%$ & Very appropriate \\
\hline & Language is very appropriate and vocabulary is very understandable & 4 & $100.0 \%$ & Very appropriate \\
\hline & Content is very accurate and contextual & 3.6 & $90.0 \%$ & Very appropriate \\
\hline & Presentation of content is structured/organized & 3.8 & $95.0 \%$ & Very appropriate \\
\hline & Users are able to use the content with minimal training (user-friendly) & 3.8 & $95.0 \%$ & Very appropriate \\
\hline \multirow[t]{3}{*}{ Text } & $\begin{array}{l}\text { The text is written with no errors in grammar, capitalization, punctuation, } \\
\text { and spelling }\end{array}$ & 3.4 & $85.0 \%$ & Very appropriate \\
\hline & $\begin{array}{l}\text { The fonts are easy-to-read and point size varies appropriately for } \\
\text { headings and text }\end{array}$ & 3.6 & $90.0 \%$ & Very appropriate \\
\hline & Fonts and colors are used to emphasize specific points & 3.2 & $80.0 \%$ & Very appropriate \\
\hline \multirow[t]{5}{*}{ Video } & Video is very aligned with the learning objectives & 4 & $100.0 \%$ & Very appropriate \\
\hline & Video can help make learning more meaningful to students & 3.8 & $95.0 \%$ & Very appropriate \\
\hline & Video production can be implemented into classroom activities & 3.6 & $90.0 \%$ & Very appropriate \\
\hline & $\begin{array}{l}\text { Video may encourage collaboration and requires students to be active and } \\
\text { constructive }\end{array}$ & 3.8 & $95.0 \%$ & Very appropriate \\
\hline & Information is correct and contextual & 4 & $100.0 \%$ & Very appropriate \\
\hline \multirow[t]{3}{*}{ Audio } & The recorder narration is very clear & 3.6 & $90.0 \%$ & Very appropriate \\
\hline & The sound effects are very attractive & 3.8 & $95.0 \%$ & Very appropriate \\
\hline & $\begin{array}{l}\text { The sound effect, music, and speeches are very compatible with each } \\
\text { other }\end{array}$ & 3.8 & $95.0 \%$ & Very appropriate \\
\hline Image & $\begin{array}{l}\text { The images consistently demonstrate the topics learned in class } \\
\text { The images are well produced and appropriate for the assignment } \\
\text { The images are connected to the contents }\end{array}$ & \begin{tabular}{l|}
4 \\
3.6 \\
4
\end{tabular} & $\begin{array}{l}100.0 \% \\
90.0 \% \\
100.0 \% \\
\end{array}$ & $\begin{array}{l}\text { Very appropriate } \\
\text { Very appropriate } \\
\text { Very appropriate }\end{array}$ \\
\hline \multirow[t]{3}{*}{ Animation } & Every presentation has different animations & 3.8 & $95.0 \%$ & Very appropriate \\
\hline & $\begin{array}{l}\text { Animations consist of a series of images that are shown in rapid } \\
\text { succession }\end{array}$ & 4 & $100.0 \%$ & Very appropriate \\
\hline & The animations are varied and displayed on the screen & 4 & $100.0 \%$ & Very appropriate \\
\hline \multirow[t]{3}{*}{ Interactivity } & The content is very interactive and easy to understand & 3.8 & $95.0 \%$ & Very appropriate \\
\hline & Users have active role in the learning process & 3.8 & $95.0 \%$ & Very appropriate \\
\hline & $\begin{array}{l}\text { The contents provide question-answer problem solving, and learning } \\
\text { activities that teach by questioning students, not just by questioning for } \\
\text { evaluation }\end{array}$ & 4 & $100.0 \%$ & Very appropriate \\
\hline \multicolumn{2}{|c|}{ Average score of respondents' reactions } & 3.77 & $94.2 \%$ & Very appropriate \\
\hline
\end{tabular}

All criteria have shown the result above $80 \%$ meaning that from the content, text, video, audio, image, animation and interactivity may both fulfill students' expectations and capabilities for learning English as the Web-based English instructional materials are facilitated with engaging materials with attractive videos and images that are very interactive. Data on the table reveals the validity score of the Web-based materials reached 3.77 in average. Theses scores located at the very appropriate level. It means that the validity level of the materials which was developed through Web-based is very appropriate and in turn, it can be applied in the instruction of General English Course.

With the intention of quantitative data from questionnaire provided, the researcher also conducted interview to some students to draw out their feelings, opinion, comments, strengths, weakness, and suggestions about the Web-based instructional materials for general English course. Fifteen students were interviewed taken from three different classes. Each student was asked five questions to get qualitative data. In order to get students' meaningful responses and minimize problem of misinterpretation, the semi interviewed were conducted in Indonesian. The students who were the interviewee agreed to the use of digital recording of the interview for an accurate reference. The researchers found the results from the five questions as follows:

Question 1: Do you like learning general English Course by using Web-based instructional materials? Why or why not?

"Ten students admitted their fondness because for them because of the convenience learning through Web-based instruction. For them, it was very flexible that they can learn from wherever and whenever"

"Five students convey that learning via Web-based instructional materials promoted them to be independent learners. They can learn constantly on their own without the lecturer. It was fun learning through Web-based materials with various activities, they said"

Question 2: What do you like and dislike most when learning English through Web-based instructional materials?

There are three different opinions concerning this question:

Seven students said that the topic of the materials particularly the speaking practice encourage us to find partner or organize group to practice. This activity stimulates us to keep talking and communicates with us. The topic was clear enough to understand. The level of difficulty of the materials was suitable for our learning ability.

Four students assumed that the exercises and the assignments are challenging. They help us to understand more by doing the exercises. When we did the exercises or the assignment, we could check the answer from the answer key provided and recognize the level of our learning mastery or achievement. What is more, the exercises or the assignments were suitable for our learning ability. 
Four students like the video animation. It is clear pronunciations and interesting conversation topics. They really encourage us to practice the conversation on the video animation.

Question 3: Are you convenient learning by equipped with Web-based English instructional materials? If not, what are problems? Would you give any suggestions or comments?

Most of the students are well-situated with the Web-based materials, nevertheless, they sometimes find the slow internet connection to be the issue. This issue makes them feel annoyed especially the long waiting process.

Another problem that encountered by students were when they used the materials out of campus and need help or assistance from the lecturer but they can't do that immediately. Although the Web-board or chat forum is available, they have to wait for the lecturer's responses or comments on the chat forum.

Question 4: How should the Web-based English instructional materials be adjusted to meet your needs?

Four students suggested to add and organize the Web-based instruction with learning menu tools and also equipped with animated pictures that can attract their learning.

Four students recommended that answers for exercises and quizzes are completed with explanations so that the students can understand comprehensively.

Seven students recommended that this Web-based instruction should have a variety of topics or themes, not only used when we study English for general course but the learning materials are still available to be used for the next time for practicing.

Question 5: Would you like the next ESP course used Web-based English instructional materials?

For this question, all students reacted positively. We prefer to have Web-based instructional materials, present the materials with integrated skills. Further, the topic should much focus on our background study program, in other words, more specific in terms of purposes.

After gathering the opinions of the students, the lecturers' opinions were also gathered in order to evaluate the effectiveness of the product in promoting independent learning. Likewise, the students, the lecturers who teach general English course were interviewed. There were three lecturers interviewed concerning the practicality or utility, the appropriateness, and the effectiveness of Web-based English instructional materials in promoting independent learning.

Question 1: How do you think the practicality of the teaching by using Web-based English instructional materials?(Practicality)

These Web-based instructional materials are really useful for me. Since the materials have been provided and suitable for my students' need and expectation. The various contents which equipped with authentic materials such as audio-visual, authentic conversation from native speakers are valuable (lecturer 1)

The Web-based instructional materials enable students to get real and authentic examples of the language expressions (lecturer 2)

The students become more enthusiastic, give more attention to learning by the means of Web-based instructional materials (lecturer 3)

Question 2: Are the contents of the Web-based instruction accurate for teaching English as general course?

The topics presented can engage the students to learn. The design of the presentation that displays integrated language skills relevant to the level of the students (lecturer 1)

The Web-based instructional materials make the classroom more enjoyable and potential to promote independent learning because of the various activities that can be accessed anytime and anywhere (lecturer 2)

The process of teaching and learning are more interesting and the students have more attention to the subject I teach (lecturer 3)

Question 3: How do you think the effectiveness of the Web-based instructional materials?

The whole packages are included; Speaking, Listening, Reading and Writing and language functions are presented so students are able to practice their language skills interchangeable (lecturer 1)

Because of the open resources software program so we are as authorized lecturers can edit the materials whenever needed. It is very effective (lecturer 1)

I can give feedback immediately to the students works or their assignment even respond to their problem faced (lecturer 2)

With the various activities in Web-based materials, they enable to eliminate the boring situation, making the classroom alive. In short, the Web-based instructional materials can create language learning easier and more successfully managed (lecturer 3)

\section{CONCLUSION}

The present teaching and learning method for General English Course implemented at Tadulako University shows inadequacy in fulfilling students' needs and expectations. The Web-based English instructional materials that are needed by the students based on research conducted through need analysis should be seen from how students perceive their objectives in learning English. The implementation of web-based English instructional materials has brought changes and positive impact on the students. The standards and indicators of students' independent learning are achieved through web-based English instructional materials. This is indicated from the students' opinions toward the content, audio-visual materials that are proven to be very positive and appropriate to be used as instructional materials. 
The students agree that the flexible learning atmosphere along with the interactive and resourceful materials, allow them to be attracted and motivated in learning independently. The fun learning atmosphere and the flexibility of lecturers' teaching method as the main feature of Web-based instructional materials are very appropriate for students particularly in helping them to be independent learners. The fact that users are able to access the materials with minimum training and do not depend on the presence of teachers prove to help students to be motivated in learning independently.

\section{REFERENCES}

[1] Aminah. A.(2016). Student and Teacher Perceptions on the role of ICT in Promoting Instruction for Quality Teaching and Learning in Central Sulawesi, Indonesia. Asian EFL Journal - Professional Teaching Article Vol. 1, 12 - 14.

[2] Chomsky, N. (1988). Language and Problems of Knowledge: The Managua Lectures. Cambridge: MIT Press.

[3] Cakir, I. (2015). Instructional Materials Commonly Employed by Foreign Language Teachers at Elementary Schools. International Electronic Journal of Elementary Education, 69-82.

[4] CIEL Project. (2000). Integrating Independent Language Learning: Management and Policy Considerations. CIEL.Available at https://www.llas.ac.uk/resources/gpg/1404.html. Retrieved on September 2015.

[5] Erricolo, D., \& Raymond, A. (2008). Web-based Instruction in Engineering [online].Available: http://www.uic.edu/eng/meng/pdfs/APMagazine.pdf5.

[6] Horton, W. (2000). Designing Web-based training. Wiley \& Sons Computer Publishing, Inc. New York.

[7] Hui, S. C., \& Cheung, K. (1999). Developing A Web-Based Learning Environment for Building Energy Efficiency and Solar Design in Hongkong. Jerusalem: ISES Solar World Congress.

[8] Ismail, C. (2015). Instructional Materials Commonly Employed by Foreign Language Teachers at Elementary Schools. International Electronic Journal of Elementary Education. 8(1), 69-82.

[9] Jaeglin. (1998). Learner's and Instructors' Attitudes Towards Computer-assisted Class Discussion. In S. J., R. S., M. P., \& A. K., Language Learning Online: Theory and Practice in the ESL and L2 Computer Classroom (pp. 121-138). Austin: Daedalus Group Inc.

[10] Jalal, F., Samani, M., Chang, M., Stevenson, R., Ragatz, A., \& Negara, S. (2009). Teacher Certification in Indonesia: A Strategy for Teacher Quality Improvement. Retrieved on March 2015 from http://documents.worldbank.org/curated/en/705901468283513711/Teacher-certification-in-Indonesia-a-strategy-for-teacherquality-improvement.

[11] Johnson, A. (2009). "The Rise of English: The Language of Globalization in China and the European Union," Macalester International: Vol. 22, Article 12. Retrieved on May 2015 from http://digitalcommons.macalester.edu/macintl/vol22/iss1/12.

[12] Kern, R., \& Warschauer, M. (2000). Theory and practice of network-based language teaching. In M. Warschauer, \& R. Kern, Network-based language teaching: Concepts and practice (pp. 1-19). New York: Cambridge University Press. Retrieved on May 2015.

[13] Khan, B. (1997). Web-based Instruction. New Jersey: Educational Technology Publication.

[14] Knight, P. (1996). Independent Study, Independent Studies and Core Skills' in Higher Education. In J. Tait, \& K. P., The Management of Independent Learning. London: Kogan Page - SEDA.

[15] Lengkanawati, N. (2005). EFL Teachers' Competence in the context of English Curriculum 2004: Implications for EFL Teacher Education. TEFLIN Journal, Volume XVI, Number 1, February 2005, pp. 79-92.

[16] Liu, H. (2013). Constructing a web-based autonomous learning model for teaching English. World Transactions on Engineering and Technology Education, 11(4) pp. 541-546.

[17] Mahmoudi, E., Samad, A., \& Razak, N. (2012). Attitude and Students' Performance in Computer Assisted English Learning (CAEL) for Learning Vocabulary. In Procedia-Social and Behavioural Sciences 66 (pp. 489-498).

[18] McCormack, C., \& Jones, D. (1998). Building a Web-based Education System. New York: Wiley Computer Publisher.

[19] Nielsen, J. (2000). Designing Web Usability: The Practice of simplicity. New Riders Publishing. Indiana, USA.

[20] Olson, T. M., Wisher, R. A. (2002). The Effectiveness of Web-Based Instruction: An initial inquiry. The International Review of Research in Open and Distributed Learning. Athabasca University. Retrieved on July 05, 2016, from http://www.irrodl.org/index.php/irrodl/article/view/103/182.

[21] Richards, J. C. (2001). Curriculum Development in Language Teaching. Cambridge: The Press Syndicate of the University of Cambridge.

[22] Sheerin, S. (1997). An Exploration of the Relationship Between Self-access and Independent Learning. Oxford: Oxford University Press.

[23] Lengkanawati, N. (2004). How Learners from Different Backgrounds Learn Foreign Language. Asian EFL Journal.

[24] Suriaman, A. (2015). Strategies in promoting independent learning through self-access center at Tadulako University. Asian EFL Journal - Professional Teaching Article/ November 2015, Issue 88, pp.29-58.

[25] Tabatabaei, M., Gui, Y. (2011). The Impact of Technology on Teaching and Languages. Education in a technological world: communicating current and emerging research and technological efforts . A. Méndez-Vilas (Ed.)

[26] Tomlinson, B. (2003). Developing Materials for Language Teaching. London: Continuum.

[27] Yaumi, M. (2013). Prinsip-Prinsip Desain Pembelajaran. Jakarta: Kencana Media Grup. 


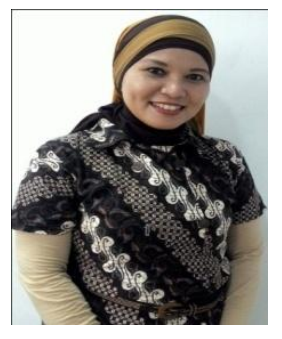

Aminah Suriaman is an English lecturer, Department of Teacher Training and Education Tadulako University, Palu Central Sulawesi Indonesia. She recently has accomplished her Doctoral Program at State University of Makassar, Indonesia.

Dr. Aminah, S.Pd., M.Pd., M.Ed, main research interests include Developing English Instructional Materials based technology as well as TEFL.

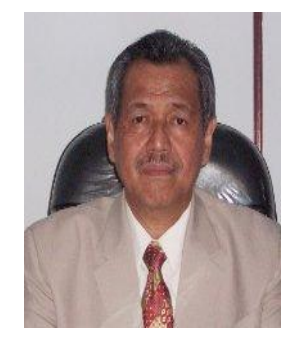

Asfah Rahman is currently an associate professor in the Faculty of Literature and Language, State University of Makassar, Makassar, Indonesia. His research interests include early reading program for learners of English as a foreign language.

Prof. Muhammad Asfah Rahman, M.Ed., Ph.D. is currently a member of Indonesian Linguistic Society (MLI), Indonesian Education Scholars Association (ISPI) and TEFLIN (Teaching English as a Foreign Language in Indonesia).

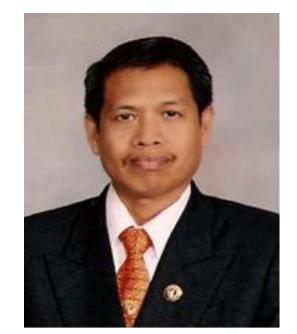

Nurdin Noni is recently an associate professor in the Faculty of Literature and Language, State University of Makassar. He has published a book entitled "Teknologi Informasi dan Komunikasi" in 2010 and scientific researchers including "The Facts about the use of Technology and Language Teaching at Senior Secondary School 2014 Proceeding ICMSTEA" and "The Development of Interactive Multimedia for First-grade Beginning Readers.

Prof. Dr. Nurdin Noni., M.Hum is a senior lecturer at State University of Makassar South Sulawesi Indonesia. 